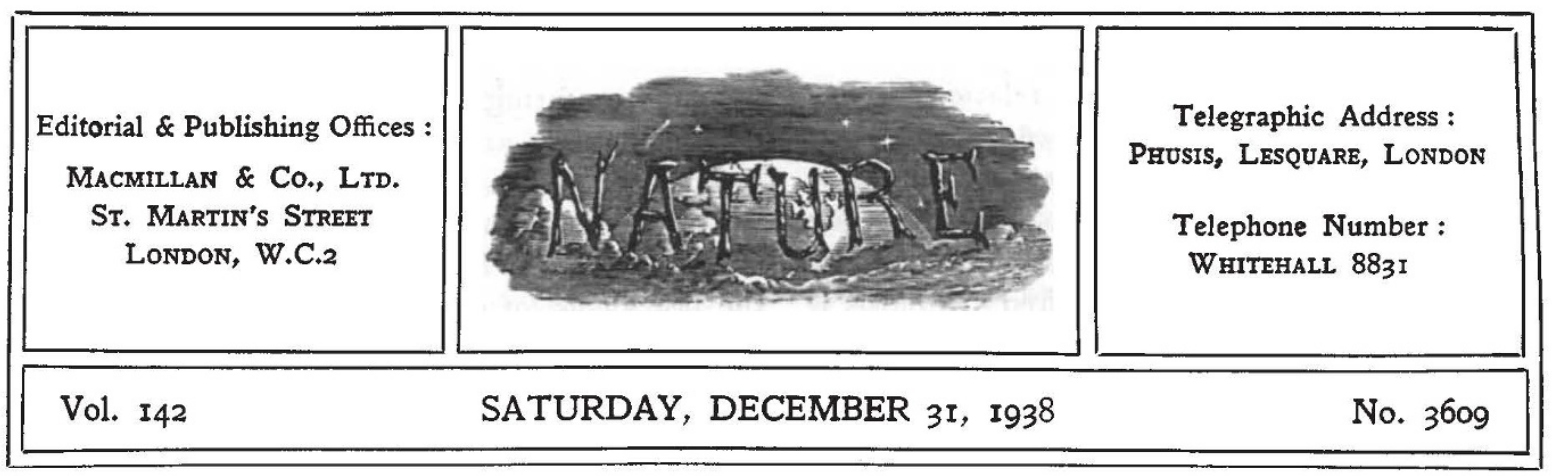

\title{
The Land in Colonial Development
}

Posto ERITY will judge the success of tropical colonization by the condition of the land at the end of the colonizing period. The fire of presently burning political, social and racial questions will be consumed in the fog of history, but the land will retain for all time marks of the treatment it receives. There is little in treatment of land that is likely ever to become front-page news: colonial polities that get into newspapers are mainly concerned with the rights of the people living on the soil or rights to the minerals beneath it. The public does not hear much of the rights of the soil. Hence the indication that at least one important section of officialdom recognizes, and encourages, the recognition of these paramount rights is significant. Evidence that this fundamentally sound point of view is gaining ground is furnished by a recent report of the Conference of Colonial Directors of Agriculture*.

The personnel of the Conference was not confined to directors and deputy directors of agriculture. Practically every British Dependency was authoritatively represented, and the meetings were also attended, by invitation, by a representative of the Union of South Africa, by officers of the Imperial Agricultural Bureaux and by leading authorities on agriculture, forestry and medicine in Great Britain. The subjects discussed by this very representative assembly of administrators and men of science included soil conservation, animal husbandry, nutrition, land settlement, produce inspection, agricultural education, and publicity.

The territories concerned are located in the tropics, where an early consequence of European colonization has been, almost without exception, to exhaust the soil, often beyond the limit of safety

* Report and Proceedings of the Conference of Colonial Directors of Agriculture held at the Colonial Office, July 1938. (Colonial No. 156, 1938.) (London: H.M. Stationery office, 1938.) 2s. 0d. net. which the stability of the soil demands. The stage of rapid exploitation has been followed, at least in British Africa, by an attempt to construct a type of society in which native interests would be accommodated within a framework of European civilization. We may say that this stage has been marked by a concentration on securing and adjusting the rights of both Europeans and natives and by an almost complete neglect of the rights of the land, which is now very insistently demanding prior consideration. A striking feature of the report of the Conference is the repeated emphasis laid by the Colonial delegates on this need for placing the land first in formulating agricultural policy. No attempt was made to formulate a policy at the Conference, the object of which was rather to obtain expressions of opinions for discussion. A policy, indeed, is not wanted so much as a balanced sense of what the land and the people require. Hitherto, the emphasis has been laid on human needs ; now one can discern a tendency to emphasize the needs of the land. The pendulum, when it swings back once more, may settle down to an intermediate position of comparative stability.

The widespread exhaustion and erosion of the soil are the clearest and most unmistakable signs that the land has hitherto been neglected in Colonial development. The Conference, therefore, gave soil conservation an early and prominent place in its discussions. Although the measures needed to counteract soil exhaustion and erosion vary considerably, it was unanimously agreed that the keynote of all conservation programmes is co-operation-between agricultural, forestry, veterinary, medical, educational, railway and public-works departments : in short, a readjustment of social conditions to conform more closely with the properties of the land. 
The essence of soil conservation is the establishment of a permanent symbiotic relationship between men and the land, to replace the symbiosis between plants and the land that has been disturbed by human settlement. It is becoming clear that domesticated animals must form a link between men and soil, if the desired symbiosis is to be achieved. A combination of animal and crop husbandry ties the farmer permanently to the land, and it is this tie, rather than the provision of manure and the diversification of crops, that constitutes the greatest value of mixed farming. At present, in many tropical countries serious erosion is being caused by overstocking; elsewhere soil exhaustion has been the result of too few animals being kept. The Conference expressed complete unanimity on the value of mixed farming in tropical agriculture, while recognizing the immense economic and psychological difficulties that its general adoption would involve.

Directly linked with the question of introducing mixed farming is that of improving human and animal nutrition. Most Colonial administrators realize the desirability of increasing the amount of protein and protective foods in the native dietary-an objective which could be attained by the general adoption of mixed farming, vegetable gardening and concentration on self-sufficient rather than export agriculture. Equally, the basic question of conditions of land tenure is very closely connected with that of soil exhaustion, but cannot be determined without reference to the type of husbandry that will finally become a permanent part of the life of the community.
Mixed farming encourages long-term tenure; annual-crop farming encourages short-term tenure in temperate, and presumably also tropical, countries. Memoranda presented by several Governments pointed to a close connexion between short-term leases, insecurity of tenure and the prevalence of erosion. The report leaves the impression that not only security of tenure but also the desire for secure tenure need to be generally increased in most tropical dependencies. Neither the average native nor the European in the tropics seems to be imbued with that innate love of, and pride in, the land which is the bedrock of European civilization. Methods of education and propaganda that were discussed at the close of the Conference are directed towards inculcating into the natives a fuller understanding of the attitude the Europeans would like them to adopt towards their land.

Until we come to this final discussion, the impression may well be formed that the reform of tropical agriculture requires only a good start at any of the key points-soil conservation, mixed farming, nutrition-and it will complete itself in the development of a stable social structure which would accommodate both black and white. But the psychological link in the chain seems weak. There is more hope than evidence that the average native will easily settle down to the mode of life demanded by mixed farming. There seem, however, to be firm grounds for believing that tropical soils would be permanently improved by mixed farming, and could then be made to support a modified form of civilization without danger of soil exhaustion.

\section{"Water, Water, Everywhere"}

\section{Theoretical Hydrodynamics}

By Prof. L. M. Milne-Thomson. Pp. xxii $+552+$ 4 plates. (London: Macmillan and Co., Ltd., 1938.) 31s. $6 d$. net.

THERE has been a flood of books on the 1 theory of the motion of fluids within the past few years. Some are good and others are not so good. Seventy-nine years ago, Besant published his "Treatise on Hydromechanics" in one volume, and in Great Britain the book remained as the authority on the subject for twenty years. Then in 1879 Lamb published his "Treatise on the
Mathematical Theory of the Motion of Fluids", and in 1888 Basset produced his two volumes on "Hydrodynamics". The subject kept on growing, and in 1912 Ramsey, after having spent eight years on the project, published his "Hydrodynamics". By this time Lamb had brought out three successively enlarged editions of his book, renaming it "Hydrodynamics", and was more than half-way through a revision of the subject prior to bringing out a fourth edition. So the race went on, and the problem was how to keep abreast of research, research which was altering vitally general ideas on the subject. By 1932 Lamb had 